\title{
Flavobacterium haoranii sp. nov., a cypermethrin- degrading bacterium isolated from a wastewater treatment system
}

\author{
Correspondence \\ Shun-Peng Li \\ Isp@njau.edu.cn
}

\author{
Jun Zhang, ${ }^{1}$ Rui-Bo Jiang, ${ }^{2}$ Xiao-Xia Zhang, ${ }^{2}$ Bao-Jian Hang, ${ }^{1}$ Jian $\mathrm{He}^{1}$ \\ and Shun-Peng $\mathrm{Li}^{1}$ \\ ${ }^{1}$ Key Laboratory of Microbiological Engineering of Agricultural Environment, Ministry of Agriculture, \\ Life Sciences College of Nanjing Agricultural University, Nanjing, Jiangsu 210095, PR China \\ ${ }^{2}$ Institute of Agricultural Resources and Regional Planning, Chinese Academy of Agricultural \\ Sciences, Beijing 100081, PR China
}

\begin{abstract}
A Gram-negative, non-spore-forming, yellow-pigmented bacterium, strain LQY- ${ }^{\top}$, was isolated from activated sludge treating synthetic pyrethroid-manufacturing wastewater. The taxonomic status of the strain was determined using a polyphasic taxonomic approach. Phylogenetic analysis based on 16S rRNA gene sequences revealed that strain LQY $-7^{\top}$ was a member of the genus Flavobacterium but had low similarities with other species of this genus $(95.0 \%$ similarity with Flavobacterium indicum GPTSA $100-9^{\top}$ and $<94 \%$ similarities with other Flavobacterium species). On the basis of phenotypic, genetic and phylogenetic data, strain LQY-7 ${ }^{\top}$ should be classified as a representative of a novel species of the genus Flavobacterium, for which the name Flavobacterium haoranii sp. nov. is proposed; the type strain is LQY $-7^{\top}$ (=ACCC $05409^{\top}$ $=\mathrm{KCTC} 23008^{\mathrm{T}}$ ).
\end{abstract}

The genus Flavobacterium was proposed by Bergey et al. (1923) and emended by Bernardet et al. (1996) to include Gram-negative, aerobic, rod-shaped, yellow-pigmented bacteria that are usually motile by gliding and have a DNA G $+\mathrm{C}$ content of $30-41 \mathrm{~mol} \%$ (Bernardet \& Bowman, 2006; Park et al., 2006). At the time of writing, the genus comprised about 60 recognized species isolated from diverse habitats such as fresh- and salt-water, diseased fish, soil, sediment and micromats.

Cypermethrin is one of the most important synthetic pyrethroid pesticides and is widely used to control pests in cotton and vegetable crops. However, cypermethrin affects the central nervous system, causes allergic skin reactions, lymph node and spleen damage, and eye irritation. In addition, cypermethrin is highly toxic to fish and other aquatic organisms, as well as to bees. It has been classified as 'moderately hazardous' (Class II) by the World Health Organization and considered as a possible human carcinogen by the US Environmental Protection Agency. Microbes play significant roles in degrading and detoxifying cypermethrin residues in the environment (Kaufman et al., 1981; Roberts \& Standen, 1981). In this paper, a cypermethrin-degrading bacterial strain, designated LQY$7^{\mathrm{T}}$, was isolated from activated sludge in a synthetic pyrethroid-manufacturing wastewater treatment facility

The GenBank/EMBL/DDBJ accession number for the $16 \mathrm{~S}$ rRNA gene sequence of strain LQY $-7^{\top}$ is GQ988780.
(Yangnong Chemical Group Co., Jiangsu Province, China). The taxonomic status of this strain was determined using a polyphasic taxonomic approach. The data obtained suggest that the isolate represents a novel species of the genus Flavobacterium.

For investigation of morphological features, strain LQY $-7^{\mathrm{T}}$ was cultivated aerobically on trypticase soy agar (TSA; Difco) at $30{ }^{\circ} \mathrm{C}$. Cell morphology and dimensions were examined by light microscopy (BH-2; Olympus) and transmission electron microscopy (H-7650; Hitachi) using cells from an exponentially growing culture. Gram-staining was performed according to the classical Gram procedure (Buck, 1982). Gliding motility, production of flexirubintype pigments and adsorption of Congo red by colonies were investigated by the methods of Bernardet et al. (2002). Growth at various temperatures $(4,10,15,20,25,30,35$, 37 and $\left.40{ }^{\circ} \mathrm{C}\right)$ and $\mathrm{pH}(4.0-10.0$ at intervals of $0.5 \mathrm{pH}$ units) was assessed on trypticase soy broth (TSB) after 3 days of incubation. Salt tolerance was tested on TSB supplemented with $0-8 \%(\mathrm{w} / \mathrm{v}) \mathrm{NaCl}$ after 3 days of incubation. Growth on nutrient agar, R2A agar, cetrimide agar, Simmons' citrate agar and MacConkey agar was also evaluated at $30{ }^{\circ} \mathrm{C}$. Sensitivity to antibiotics was tested on TSA plates using discs containing the following antibiotics: erythromycin $(15 \mu \mathrm{g})$, tetracycline $(30 \mu \mathrm{g})$, gentamicin $(10 \mu \mathrm{g})$, chloramphenicol $(30 \mu \mathrm{g})$, kanamycin $(30 \mu \mathrm{g})$, streptomycin $(10 \mu \mathrm{g})$, rifampicin $(5 \mu \mathrm{g})$, ampicillin $(10 \mu \mathrm{g})$, polymyxin B $(30 \mu \mathrm{g})$, penicillin $\mathrm{G}(1 \mu \mathrm{g})$, 
cefradine $(30 \mu \mathrm{g})$, roxithromycin $(15 \mu \mathrm{g})$, lincomycin $(2 \mu \mathrm{g})$, carbenicillin $(100 \mu \mathrm{g})$, spectinomycin $(100 \mu \mathrm{g})$, amoxicillin $(10 \mu \mathrm{g})$, bacitracin $(0.04 \mu \mathrm{g})$ and vancomycin $(30 \mu \mathrm{g})$. Standard physiological tests were carried out according to the methods described by Lányí (1987). Additional physiological characteristics were determined with the API 20NE, API 50CH and API ZYM (bioMerieux) systems according to the manufacturer's instructions.

For analysis of fatty acids, the strain was grown at $30{ }^{\circ} \mathrm{C}$ on TSB. Cells were harvested during the exponential phase by centrifugation, washed with distilled water and freezedried. The cellular fatty acids in the freeze-dried cells were identified by the Identification Service of the DSMZ (Braunschweig, Germany) as described by Kämpfer \& Kroppenstedt (1996), Kuykendall et al. (1988) and Miller (1982).

Extraction and purification of total DNA was carried out according to standard procedures (Sambrook \& Russell, 2001). The DNA G + C content was determined by thermal denaturation (Marmur \& Doty, 1962) using Escherichia coli $\mathrm{K}-12$ as a standard. Amplification of the $16 \mathrm{~S}$ rRNA gene was performed by PCR using a bacterial universal primer set (27F and 1492R; Lane, 1991). The PCR product was purified using the AxyPrep PCR Purification kit (AxyGen) and sequenced using an automated sequencer (Applied Biosystems model 3730). Similarity searches were performed using the NCBI program BLAST (http://www.ncbi.nlm.nih. gov/blast/Blast.cgi) and the sequence match program of the Ribosomal Database Project (http://rdp.cme.msu.edu/ seqmatch). A phylogenetic tree of strain LQY $-7^{\mathrm{T}}$ and closely related strains was reconstructed using the software package MEGA version 3.1 (Kumar et al., 2004) after multiple alignment of data using CLUSTAL_X (Thompson et al., 1997). Distances were calculated according to the Kimura two-parameter model (Kimura, 1980, 1983) and clustering was performed by the neighbour-joining method (Saitou \& Nei, 1987). Bootstrap analysis of 1200 resamplings was used to evaluate tree topology (Felsenstein, 1993).

An almost complete 16S rRNA gene sequence (1438 bp) was obtained for strain LQY-7 ${ }^{\mathrm{T}}$. Similarity search results in the Ribosomal Database Project and GenBank indicated that strain LQY $-7^{\mathrm{T}}$ was a member of the genus Flavobacterium. It shared $95.0 \%$ similarity with Flavobacterium indicum GPTSA $100-9^{\mathrm{T}}$ and $<94 \%$ similarities with other Flavobacterium species. A tree (Fig. 1) depicting the phylogenetic relationships of strain LQY-7 ${ }^{\mathrm{T}}$ with closely related strains demonstrated that the strain formed a subclade with $F$.

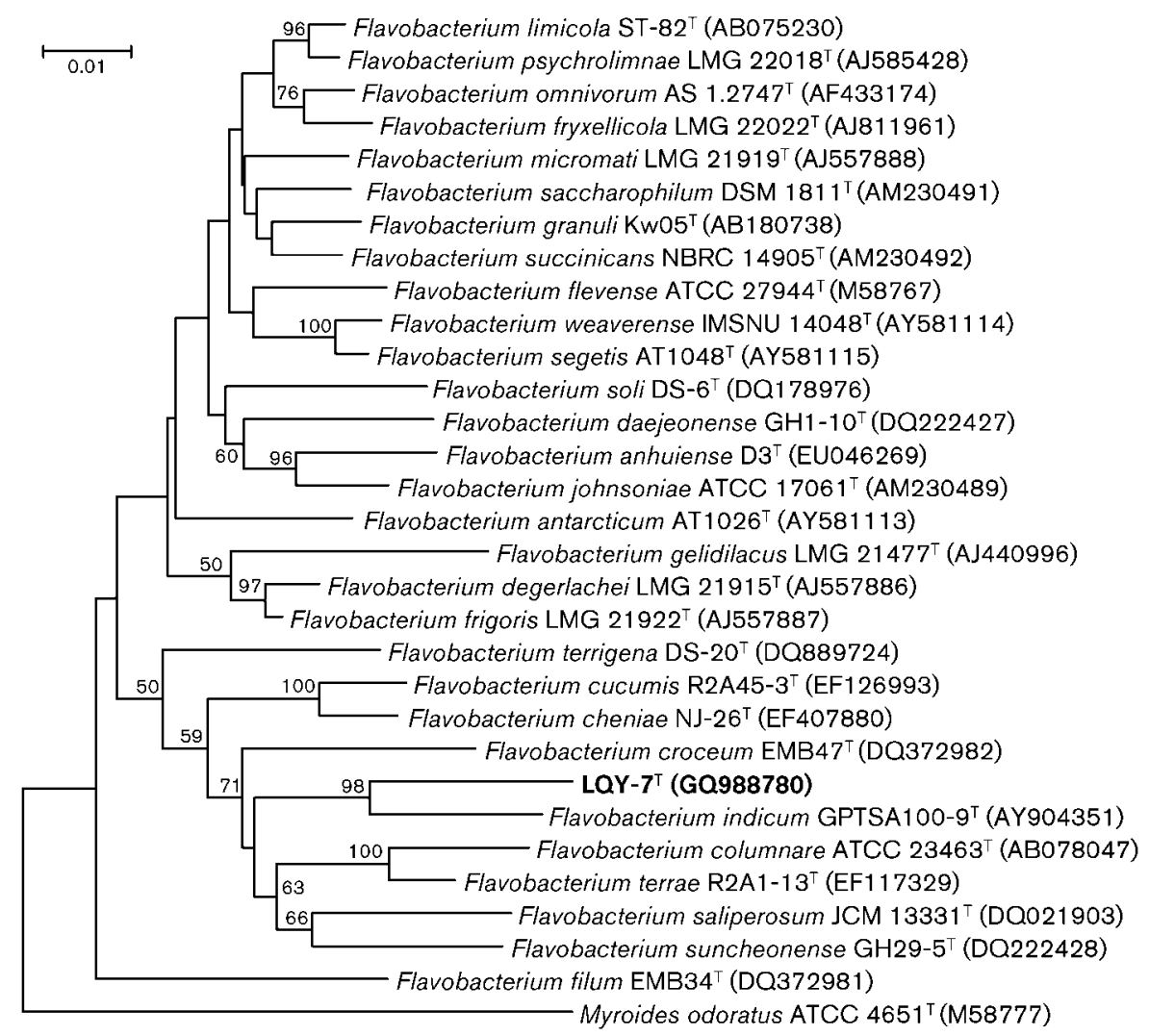

Fig. 1. Neighbour-joining tree showing the phylogenetic relationship between strain LQY $-7^{\top}$ and related species based on $16 \mathrm{~S}$ rRNA gene sequences. Bootstrap values (expressed as percentages of 1200 replications) are indicated at the branch-points. Bar, evolutionary distance $\left(K_{\text {nuc }}\right)$ of 0.01 . 
Table 1. Cellular fatty acid composition (\%) of strain LQY $-7^{\top}$ and closely related species of the genus Flavobacterium

Strains: 1, strain LQY-7 ${ }^{\mathrm{T}}$ (this study); 2, F. indicum GPTSA100-9 ${ }^{\mathrm{T}}$ (Saha \& Chakrabarti, 2006); 3, F. cucumis R2A45-3 ${ }^{\mathrm{T}}$ (Weon et al., 2007); 4, F. columnare ATCC $23463^{\mathrm{T}}$ (Weon et al., 2007); 5. F. terrae R2A1-13 ${ }^{\mathrm{T}}$ (Weon et al., 2007); 6, F. suncheonense KACC 11423 ${ }^{\mathrm{T}}$ (Kim et al., 2006); 7, F. saliperosum $\mathrm{S} 13^{\mathrm{T}}$ (Wang et al., 2006); 8, F. cheniae $\mathrm{NJ}-26^{\mathrm{T}}$ (Qu et al., 2008). -, <1\% or not detected; NR, not reported.

\begin{tabular}{|c|c|c|c|c|c|c|c|c|}
\hline Fatty acid & 1 & 2 & 3 & 4 & 5 & 6 & 7 & 8 \\
\hline $\mathrm{C}_{15: 0}$ & 1.1 & NR & - & NR & - & NR & 4.6 & 15.4 \\
\hline$C_{16: 0}$ & - & NR & 1.2 & 1.1 & - & 1.0 & NR & - \\
\hline $\mathrm{C}_{15: 0} 2-\mathrm{OH}$ & - & NR & - & NR & - & NR & NR & - \\
\hline $\mathrm{C}_{15: 0} 3-\mathrm{OH}$ & - & NR & 1.5 & 1.9 & 2.2 & NR & NR & 1.4 \\
\hline $\mathrm{C}_{16: 0} 3-\mathrm{OH}$ & - & NR & 1.7 & $\mathrm{NR}$ & 1.3 & NR & NR & - \\
\hline iso- $\mathrm{C}_{13: 0}$ & 1.0 & NR & - & 1.3 & - & 1.9 & - & - \\
\hline iso- $\mathrm{C}_{14: 0}$ & - & $\mathrm{NR}$ & 5.3 & 3.8 & 4.7 & $\mathrm{NR}$ & 1.3 & - \\
\hline iso- $\mathrm{C}_{15: 0}$ & 39.5 & 18.5 & 17.5 & 30.1 & 18.4 & 29.9 & 28.2 & 27.7 \\
\hline iso- $\mathrm{C}_{16: 0}$ & - & 5.1 & 18.8 & 8.7 & 16.6 & 1.0 & 6.9 & - \\
\hline iso- $\mathrm{C}_{16: 1}$ & - & $\mathrm{NR}$ & 4.0 & 4.1 & 3.0 & $\mathrm{NR}$ & NR & - \\
\hline iso- $\mathrm{C}_{15: 1} \mathrm{G}$ & 26.3 & 18.0 & 9.9 & 14.6 & 10.7 & 12.0 & 6.7 & 7.2 \\
\hline iso- $\mathrm{C}_{14: 0} 3-\mathrm{OH}$ & - & NR & 1.8 & 1.5 & 1.1 & NR & NR & - \\
\hline iso- $\mathrm{C}_{15: 0} 3-\mathrm{OH}$ & 5.6 & 5.0 & 5.1 & 5.2 & 6.7 & 11.1 & 5.0 & 6.3 \\
\hline iso- $\mathrm{C}_{16: 0} 3-\mathrm{OH}$ & - & 4.5 & 12.6 & 7.4 & 5.0 & $\mathrm{NR}$ & 2.0 & - \\
\hline iso- $\mathrm{C}_{17: 0} 3-\mathrm{OH}$ & 7.9 & 9.0 & 5.3 & 6.6 & 10.3 & 17.7 & 8.6 & 7.6 \\
\hline $\mathrm{C}_{15: 1} \omega 6 c$ & - & NR & 2.0 & NR & 1.1 & NR & NR & 2.7 \\
\hline iso- $\mathrm{C}_{17: 1} \omega 9 c$ & 1.5 & NR & 1.5 & 3.7 & 6.2 & 7.5 & 19.0 & 15.5 \\
\hline anteiso- $\mathrm{C}_{15: 0}$ & 6.3 & NR & 4.4 & 2.2 & 2.8 & 2.1 & 3.9 & 2.0 \\
\hline Unknown 11.543 & 1.1 & NR & NR & NR & NR & NR & NR & NR \\
\hline Unknown 13.565 & 3.1 & NR & NR & $\mathrm{NR}$ & $\mathrm{NR}$ & $\mathrm{NR}$ & NR & 1.6 \\
\hline Summed feature $3^{\star}$ & - & 16.6 & 2.0 & NR & 1.3 & 9.8 & NR & 2.5 \\
\hline
\end{tabular}

${ }^{*}$ Summed feature 3 contains $\mathrm{C}_{16: 1} \omega 7 c$ and/or iso- $\mathrm{C}_{15: 0} 2-\mathrm{OH}$.

indicum GPTSA $100-9^{\mathrm{T}}$ with a high bootstrap value (98\%), also indicating that this isolate probably represents a novel member of the genus Flavobacterium.

Chemotaxonomically, the major fatty acids $(>5 \%)$ of the strain included iso- $\mathrm{C}_{15: 0}(39.5 \%)$, iso- $\mathrm{C}_{15: 1} \mathrm{G}(26.3 \%)$, iso- $\mathrm{C}_{17: 0} 3-\mathrm{OH}(7.9 \%)$, anteiso- $\mathrm{C}_{15: 0}(6.3 \%)$ and iso$\mathrm{C}_{15: 0} 3-\mathrm{OH}(5.6 \%)$, which is in agreement with the profiles for most species of the genus Flavobacterium. Detailed fatty acid profiles are given in Table 1.

The novel strain was Gram-negative, non-spore-forming and rod-shaped $(0.3-0.7 \times 1.3-2.0 \mu \mathrm{m})$; gliding motility was not observed, Congo red was not absorbed and flexirubin-type pigments were not produced. Colonies on TSA were yellow, glistening, sticky, convex and circular with entire margins. Growth was observed at $15-37^{\circ} \mathrm{C}$ (optimum, $30^{\circ} \mathrm{C}$ ), at $\mathrm{pH}$ 6.0-8.5 (optimum, $\mathrm{pH}$ 7.0) and in $0-5 \% \mathrm{NaCl}$ (optimum, 1\%). Good growth was observed on nutrient agar and TSA. Weak growth occurred on R2A agar. No growth occurred on cetrimide agar, Simmons' citrate agar or MacConkey agar. The G+C content of the genomic DNA was $34 \mathrm{~mol} \%$, which fell within the range of $30-42 \mathrm{~mol} \%$ reported for the genus Flavobacterium (Bernardet \& Bowman, 2006). Phenotypic characteristics that differentiate strain LQY $-7^{\mathrm{T}}$ from related Flavobacterium species are listed in Table 2.
Therefore, on the basis of its phenotypic and phylogenetic characteristics, strain LQY- $7^{\mathrm{T}}$ should be classified as a representative of a novel species of the genus Flavobacterium, for which the name Flavobacterium haoranii sp. nov. is proposed.

\section{Description of Flavobacterium haoranii sp. nov.}

Flavobacterium haoranii (hao.ran'i.i. N.L. gen. masc. n. haoranii of Hao-Ran, in honour of Hao-Ran Jian, a respected Chinese microbiologist, for his enormous contributions to the establishment and development of environmental microbiology in China).

Cells are Gram-negative rods, $0.3-0.7 \mu \mathrm{m}$ in width and $1.3-2.0 \mu \mathrm{m}$ in length, non-spore-forming and non-motile. Congo red is not absorbed and flexirubin-type pigments are not produced. Colonies on TSA are yellow, circular and convex with entire margins. Grows at $15-37{ }^{\circ} \mathrm{C}$, at $\mathrm{pH} 6.0$ 8.5 and in $0-5 \% \mathrm{NaCl}$. Good growth occurs on nutrient agar and TSA; weak growth occurs on R2A agar. No growth occurs on cetrimide agar, Simmons' citrate agar or MacConkey agar. Starch, gelatin and aesculin are degraded, but casein, cellulose, agar, pectin, chitin, DNA, tyrosine and egg yolk are not. Positive for catalase and oxidase. The Voges-Proskauer test is negative. In API 20NE tests, nitrate reduction, indole production, glucose fermentation, 
Table 2. Differential phenotypic characteristics of strain LQY- $7^{\top}$ and type strains of closely related species of the genus Flavobacterium

Strains: 1, strain LQY-7 ${ }^{\mathrm{T}}$ (this study); 2, F. indicum GPTSA100-9 ${ }^{\mathrm{T}}$ (Saha \& Chakrabarti, 2006); 3, F. cucumis R2A45-3 $3^{\mathrm{T}}$ (Weon et al., 2007); 4, F. columnare ATCC $23463^{\mathrm{T}}$ (Bernardet \& Grimont, 1989; Bernardet et al., 1996); 5, F. terrae R2A1-13 ${ }^{\mathrm{T}}$ (Weon et al., 2007); 6, F. suncheonense KACC $11423^{\mathrm{T}}$ (Kim et al., 2006); 7, F. saliperosum S13 ${ }^{\mathrm{T}}$ (Wang et al., 2006); 8, F. cheniae NJ-26 ${ }^{\mathrm{T}}$ (Qu et al., 2008). +, Positive; -, negative; w, weakly positive; NR, not reported; Y, yellow; GY, greenish yellow; YO, yellowish orange.

\begin{tabular}{|c|c|c|c|c|c|c|c|c|}
\hline Characteristic & 1 & 2 & 3 & 4 & 5 & 6 & 7 & 8 \\
\hline TSA & + & - & $\mathrm{W}$ & - & $\mathrm{W}$ & $\mathrm{W}$ & $\mathrm{W}$ & $\mathrm{W}$ \\
\hline Colony pigmentation & $\mathrm{Y}$ & YO & $\mathrm{Y}$ & GY & YO & $\mathrm{Y}$ & $\mathrm{Y}$ & $\mathrm{Y}$ \\
\hline Oxidase & + & + & + & + & + & + & - & + \\
\hline Catalase & + & $\mathrm{W}$ & + & + & - & + & + & + \\
\hline Flexirubin reaction & - & - & - & + & + & - & + & - \\
\hline Gliding motility & - & - & + & + & - & - & - & + \\
\hline Glucose utilization & - & $\mathrm{w}$ & - & - & - & - & NR & - \\
\hline \multicolumn{9}{|l|}{ Hydrolysis of: } \\
\hline Starch & + & + & + & - & + & - & - & + \\
\hline Aesculin & + & - & + & - & - & - & - & $\mathrm{NR}$ \\
\hline D-Fructose & - & + & NR & - & $\mathrm{NR}$ & - & - & - \\
\hline DNA G $+C$ content $(\mathrm{mol} \%)$ & 34 & 31 & 38 & 32 & 34 & 39 & 41 & 40.6 \\
\hline
\end{tabular}

arginine dihydrolase and $\beta$-galactosidase are negative, but urease and aesculin hydrolysis are positive; does not assimilate all carbohydrates tested. In API ZYM tests, alkaline phosphatase, esterase C4, esterase lipase C8, cystine arylamidase, trypsin, $\alpha$-chymotrypsin, leucine arylamidase, valine arylamidase, acid phosphatase, naphthol-AS-BIphosphohydrolase and $\alpha$-glucosidase activities are present. Lipase C14, $\alpha$-galactosidase, $\beta$-galactosidase, $\beta$-glucuronidase, $N$-acetyl- $\beta$-glucosaminidase, $\beta$-glucosidase, $\alpha$-mannosidase and $\alpha$-fucosidase activities are absent. In API $50 \mathrm{CH}$ tests, acid is produced from aesculin, maltose, inulin and starch. Sensitive to erythromycin, chloramphenicol, rifampicin, spectinomycin, cefradine, streptomycin, ampicillin, polymyxin B, tetracycline, penicillin $\mathrm{G}$, lincomycin, carbenicillin, amoxicillin and vancomycin; resistant to roxithromycin, gentamicin, kanamycin and bacitracin.

The type strain is LQY $-7^{\mathrm{T}}$ (=ACCC $05409^{\mathrm{T}}=\mathrm{KCTC}$ $\left.23008^{\mathrm{T}}\right)$, isolated from activated sludge in a synthetic pyrethroid-manufacturing wastewater treatment facility (Yangnong Chemical Group Co., Jiangsu Province, China).

\section{Acknowledgements}

We are grateful to Dr Susanne Verbarg and Dr B. J. Tindall (German Collection of Microorganisms and Cell Cultures) for analysis of the cellular fatty acids. This work was supported by the National Natural Science Foundation of China (30970099), the National High Technology
Research and Development Program of China (2006AA10Z402) and the Social Development Program Fund of Jiangsu Province (BS2007056).

\section{References}

Bergey, D. H., Harrison, F. C., Breed, R. S., Hammer, B. W. \& Huntoon, F. M. (editors) (1923). Genus II. Flavobacterium gen. nov. In Bergey's Manual of Determinative Bacteriology, 1st edn, pp. 97-117. Baltimore: Williams \& Wilkins.

Bernardet, J.-F. \& Bowman, J. P. (2006). The genus Flavobacterium. In The Prokaryotes: a Handbook on the biology of bacteria, 3rd edn, vol. 7, pp. 481-531. Edited by M. Dworkin, S. Falkow, E. Rosenberg, K. H. Schleifer \& E. Stackebrandt. New York: Springer.

Bernardet, J.-F. \& Grimont, P. A. D. (1989). Deoxyribonucleic acid relatedness and phenotypic characterization of Flexibacter columnaris sp. nov., nom. rev., Flexibacter psychrophilus sp. nov., nom. rev., and Flexibacter maritimus Wakabayashi, Hikida, and Masumura 1986. Int J Syst Bacteriol 39, 346-354.

Bernardet, J.-F., Segers, P., Vancanneyt, M., Berthe, F., Kersters, K. \& Vandamme, P. (1996). Cutting a Gordian knot: emended classification and description of the genus Flavobacterium, emended description of the family Flavobacteriaceae, and proposal of Flavobacterium hydatis nom. nov. (basonym, Cytophaga aquatilis Strohl and Tait 1978). Int J Syst Bacteriol 46, 128-148.

Bernardet, J.-F., Nakagawa, Y. \& Holmes, B. (2002). Proposed minimal standards for describing new taxa of the family Flavobacteriaceae and emended description of the family. Int J Syst Evol Microbiol 52, 1049-1070.

Buck, J. D. (1982). Nonstaining (KOH) method for determination of gram reactions of marine bacteria. Appl Environ Microbiol 44, 992-993. 
Felsenstein, J. (1993). PHYLIP (phylogeny inference package), version 3.5c. Distributed by the author. Department of Genome Sciences, University of Washington, Seattle, USA.

Kämpfer, P. \& Kroppenstedt, R. M. (1996). Numerical analysis of fatty acid patterns of coryneform bacteria and related taxa. Can $J$ Microbiol 42, 989-1005.

Kaufman, D. D., Russell, B. A., Helling, C. S. \& Kayser, A. J. (1981). Movement of cypermethrin, decamethrin, permethrin and their degradation products in soil. J Agric Food Chem 29, 239-245.

Kim, B.-Y., Weon, H.-Y., Cousin, S., Yoo, S.-H., Kwon, S.-W., Go, S.-J. \& Stackebrandt, E. (2006). Flavobacterium daejeonense sp. nov. and Flavobacterium suncheonense sp. nov., isolated from greenhouse soils in Korea. Int J Syst Evol Microbiol 56, 1645-1649.

Kimura, M. (1980). A simple method for estimating evolutionary rates of base substitutions through comparative studies of nucleotide sequences. J Mol Evol 16, 111-120.

Kimura, M. (1983). The Neutral Theory of Molecular Evolution. Cambridge: Cambridge University Press.

Kumar, S., Tamura, K. \& Nei, M. (2004). MEGA3: integrated software for molecular evolutionary genetics analysis and sequence alignment. Brief Bioinform 5, 150-163.

Kuykendall, L. D., Roy, M. A., O'Neill, J. J. \& Devine, T. E. (1988). Fatty acids, antibiotic resistance, and deoxyribonucleic acid homology groups of Bradyrhizobium japonicum. Int J Syst Bacteriol 38, 358-361.

Lane, D. J. (1991). 16S/23S rRNA sequencing. In Nucleic Acid Techniques in Bacterial Systematics, pp. 115-175. Edited by E. Stackebrandt \& M. Goodfellow. Chichester: Wiley.

Lányí, B. (1987). Classical and rapid identification methods for medically important bacteria. Methods Microbiol 19, 1-67.

Marmur, J. \& Doty, P. (1962). Determination of the base composition of deoxyribonucleic acid from its thermal denaturation temperature. J Mol Biol 5, 109-118.
Miller, L. T. (1982). Single derivatization method for routine analysis of bacterial whole-cell fatty acid methyl esters, including hydroxy acids. J Clin Microbiol 16, 584-586.

Park, M., Lu, S., Ryu, S. H., Chung, B. S., Park, W., Kim, C. J. \& Jeon, C. O. (2006). Flavobacterium croceum sp. nov., isolated from activated sludge. Int J Syst Evol Microbiol 56, 2443-2447.

Qu, J.-H., Li, H.-F., Yang, J.-S. \& Yuan, H.-L. (2008). Flavobacterium cheniae sp. nov., isolated from sediment of a eutrophic reservoir. Int $J$ Syst Evol Microbiol 58, 2186-2190.

Roberts, T. R. \& Standen, M. E. (1981). Further studies of the degradation of the pyrethroid insecticide cypermethrin in soils. Pestic Sci 12, 285-296.

Saha, P. \& Chakrabarti, T. (2006). Flavobacterium indicum sp. nov., isolated from warm spring water in Assam, India. Int J Syst Evol Microbiol 56, 2617-2621.

Saitou, N. \& Nei, M. (1987). The neighbor-joining method: a new method for reconstructing phylogenetic trees. Mol Biol Evol 4, 406425.

Sambrook, J. \& Russell, D. W. (2001). Molecular Cloning: a Laboratory Manual, 3rd edn. Cold Spring Harbor, NY: Cold Spring Harbor Laboratory Press.

Thompson, J. D., Gibson, T. J., Plewniak, F., Jeanmougin, F. \& Higgins, D. G. (1997). The CLUSTAL_X windows interface: flexible strategies for multiple sequence alignment aided by quality analysis tools. Nucleic Acids Res 25, 4876-4882.

Wang, Z.-W., Liu, Y.-H., Dai, X., Wang, B.-J., Jiang, C.-Y. \& Liu, S.-J. (2006). Flavobacterium saliperosum sp. nov., isolated from freshwater lake sediment. Int J Syst Evol Microbiol 56, 439-442.

Weon, H. Y., Song, M. H., Son, J.-A., Kim, B.-Y., Kwon, S.-W., Go, S.-J. \& Stackebrandt, E. (2007). Flavobacterium terrae sp. nov. and Flavobacterium cucumis sp. nov., isolated from greenhouse soil. Int $J$ Syst Evol Microbiol 57, 1594-1598. 